Research note

\title{
Rediscovery of Pachysentis gethi (Acanthocephala: Oligacanthorhynchidae), a parasite of wild lesser grison Galictis cuja (Carnivora: Mustelidae) from Brazil
}

\author{
Redescubrimiento de Pachysentis gethi (Acanthocephala: Oligacanthorhynchidae), parásito \\ del grisón menor silvestre Galictis cuja (Carnivora: Mustelidae) de Brasil \\ Luís C. Muniz-Pereira $^{\mathrm{a}}$, Pilar Corrêa ${ }^{\mathrm{a}, *}$, Cecília Bueno $^{\mathrm{b}}$, Fabiano M. Vieira $^{\mathrm{a}}$ \\ ${ }^{a}$ Laboratório de Helmintos Parásitos de Vertebrados, Instituto Oswaldo Cruz, FIOCRUZ, Av. Brasil 4365, Rio de Janeiro, Rio de Janeiro CEP 21040-900, Brazil \\ ${ }^{\mathrm{b}}$ Laboratório de Ecologia, Universidade Veiga de Almeida, Rua Ibituruna, 108, Rio de Janeiro CEP 20271-901, Brazil \\ Received 1 August 2015; accepted 13 June 2016 \\ Available online 20 November 2016
}

\begin{abstract}
We report the acanthocephalan Pachysentis gethi parasitizing lesser grison Galictis cuja from Brazil. This study is the first report of this acanthocephalan species since the original description from 1950. Therefore, this report constitutes the rediscovery of this parasite after 65 years of its unique record.

(C) 2016 Universidad Nacional Autónoma de México, Instituto de Biología. This is an open access article under the CC BY-NC-ND license (http://creativecommons.org/licenses/by-nc-nd/4.0/).
\end{abstract}

Keywords: Acanthocephala; Neotropical region; Carnivore mammal; Parasite

\section{Resumen}

Reportamos el acantocéfalo Pachysentis gethi parasitando a Galictis cuja en Brasil. Desde la descripción original hecha en 1950, este es el primer registro para la especie. Por ello, este informe representa el redescubrimiento de $P$. gethi desde su único registro hace 65 años. (C) 2016 Universidad Nacional Autónoma de México, Instituto de Biología. Este es un artículo Open Access bajo la licencia CC BY-NC-ND (http://creativecommons.org/licenses/by-nc-nd/4.0/).

Palabras clave: Acantocéfala; Región neotropical; Mamífero carnívoro; Parásito

During a helminthological survey in a population of wild lesser grison Galictis cuja (Molina, 1872) (Carnivora, Mustelidae), 18 specimens of this host species were necropsied. The specimens examined were accidental 'road kills' on the Federal highway BR-040 between the cities of Três Rios, state of Rio de Janeiro (RJ), km $11\left(22^{\circ} 02^{\prime} 49^{\prime \prime} \mathrm{S}, 43^{\circ} 12^{\prime} 02^{\prime \prime} \mathrm{W}\right)$, and Simão Pereira, state of Minas Gerais (MG), km $827\left(22^{\circ} 00^{\prime} 08^{\prime \prime} \mathrm{S}\right.$, $43^{\circ} 16^{\prime} 36^{\prime \prime} \mathrm{W}$ ), in the southeast region, Brazil, between 2009

\footnotetext{
* Corresponding author.

E-mail address: pi.correa@ hotmail.com (P. Corrêa)

Peer Review under the responsibility of Universidad Nacional Autónoma de México.
}

and 2014. The Brazilian Institute of Environment and Natural Resources authorized the sampling - IBAMA/SISBIO (Request No. 30727-4).

The hosts were identified according to Yensen and Tarifa (2003) and Bornholdt et al. (2013) by the absence of a metaconoid in the inferior premolar tooth, characteristic of G. cuja. The hosts parasitized by acanthocephalans were deposited in the Mastozoology Collection of the National Museum of Rio de Janeiro of Universidade Federal do Rio de Janeiro (MNRJ/UFRJ) (MNRJ 79162, MNRJ 79190, MNRJ 79261, MNRJ 79294 and MNRJ 79407).

The acanthocephalans were fixed in AFA (70\% ethanol, 93 parts; $37 \%$ formalin, 5 parts; glacial acetic acid, 2 parts) 

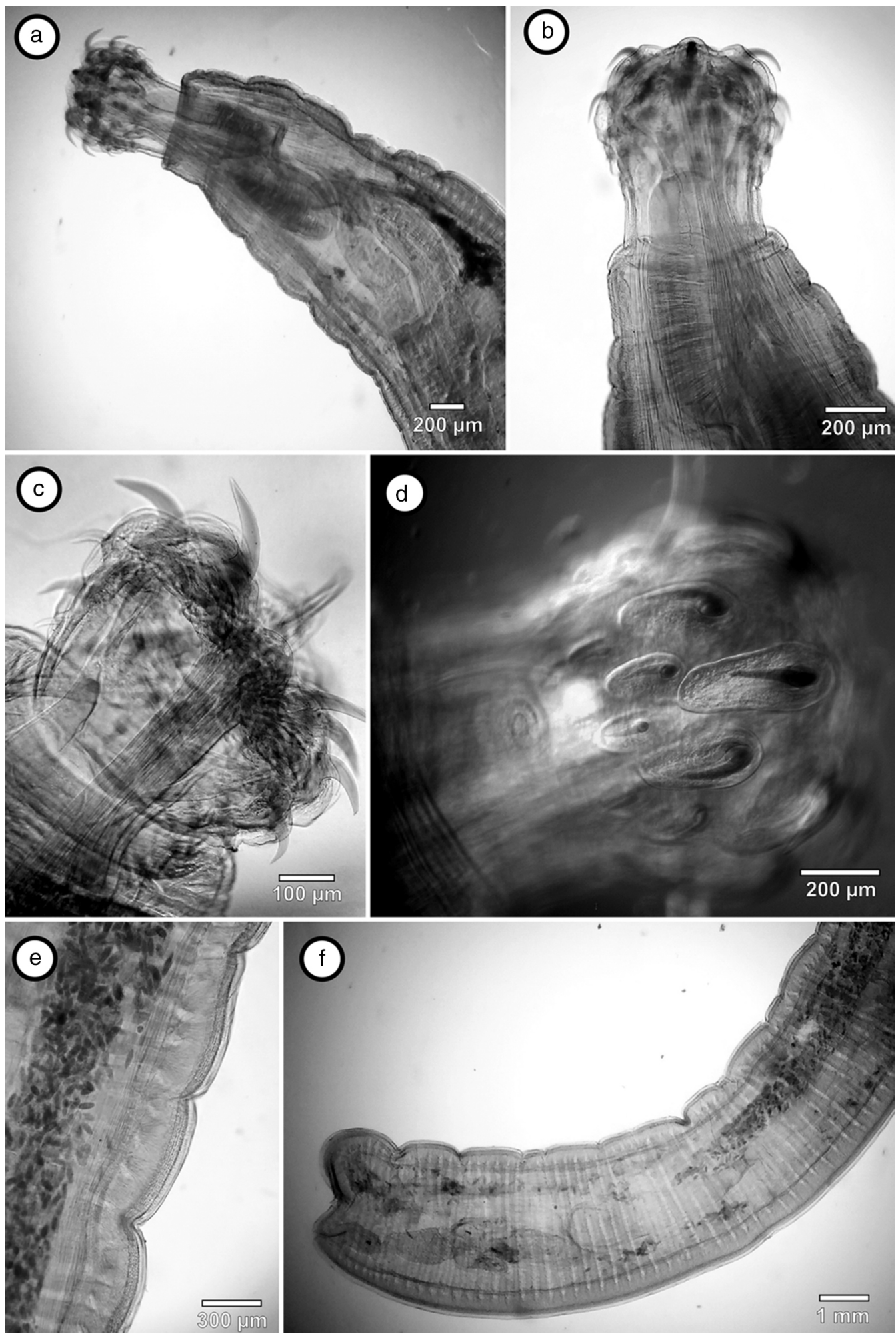

Figure 1. Female specimen of Pachysentis gethi. (a) Anterior region, lateral view; (b) anterior region, ventral view; (c) anterior end, detail of proboscis, lateral view; (d) anterior end, detail of hooks and roots of hooks, ventral view; (e) details of the location of eggs, lateral view; (f) posterior region, detail of apical genital pore, lateral view.

for $48 \mathrm{~h}$, stored in ethanol $70^{\circ} \mathrm{GL}$, stained in Delafield's Hematoxylin and mounted in Canada balsam on permanent slides for specific identification. The specimens were identified and digital images were recorded with an Olympus BX-51 microscope light microscope equipped with Nomarski differential interference contrast (DIC) optics. Identification of acanthocephalan worms was based on Machado-Filho (1950) and Schmidt (1972). Voucher specimens were deposited in the Helminthological 
Collection of Oswaldo Cruz Institute (CHIOC 38100), Rio de Janeiro, RJ.

The prevalence of parasitism by Pachysentis gethi (MachadoFilho, 1950) (Fig. 1) in lesser grison of this current study was $27.7 \%$ (5 infected hosts), with a mean intensity of 2.6 parasites per infected host, and mean abundance of 0.7 parasites per examined host.

Meyer (1931) proposed the genus Pachysentis to include the species P. ehrenbergi Meyer, 1931, P. canicola Meyer, 1931, and $P$. procumbens Meyer, 1931, from Brazilian and Egyptian carnivores. Currently, 10 nominal species of this parasitic genus in mammal hosts around the world are considered valid: Pachysentis angolensis (Golvan, 1957), P. canicola Meyer, 1931 (type species), Pachysentis dollfusi (Machado-Filho, 1950), P. ehrenbergi Meyer, 1931, P. gethi, Pachysentis lenti (MachadoFilho, 1950), P. procumbens Meyer, 1931, Pachysentis procyonis (Machado-Filho, 1950), Pachysentis rugosus (Machado-Filho, 1950) and Pachysentis septemserialis (Machado-Filho, 1950) (Amin, 2013).

In Brazil, 5 species of Pachysentis have been reported (Machado-Filho, 1950; Vieira, Luque, \& Muniz-Pereira, 2008). P. lenti was described parasitizing Callithrix geoffroyi (Humboldt, 1812) (Primates, Callitrichidae) from the state of Espirito Santo; P. procyonis (Machado-Filho, 1950) is a parasite of Procyon cancrivorus (Cuvier, 1789) (Carnivora, Procyonidae) in the state of Rio de Janeiro; P. rugosus (Machado-Filho, 1950) was reported in the large intestine of Cebus cay (Illiger, 1815) (Primates, Cebidae) in the state of Rio de Janeiro; P. septemserialis (Machado-Filho, 1950) is a parasite of Saguinus ursulus Hoffmannsegg, 1807 (Primates, Cebidae) in the state of Pará; and $P$. gethi was described as a parasite of Eira barbara Linnaeus, 1758 (Carnivora, Mustelidae) in the states of Pará and Rio de Janeiro (Machado-Filho, 1950).

Schmidt (1972) transferred the species $P$. dollfusi, P. gethi, $P$. lenti, P. procyonis, $P$. rugosus and $P$. septemserialis from the genus Prosthenorchis Travassos, 1915 to the genus Pachysentis. This taxonomical change was made mainly because these species do not possess a conspicuous festooned collar at the base of proboscis, and by having 12 longitudinal rows of hooks (in apical view), showing a total of between 42 and 102 hooks in the proboscis.

In the current study, we collected only female specimens of this acanthocephalan. The specimens studied have the similar morphometric (Table 1) and morphologic features of females of P. gethi described by Machado-Filho (1950). In the specimens of the current study, we observed that the hooks of the first 4 rows have a double root, and the other rows are of simple root, the same was reported in the specimens of $P$. gethi described by Machado-Filho (1950).

P. gethi was originally described as a parasite of the carnivore mustelid gray headed tayra (E. barbara) in a state of the northern region of Brazil (Pará), and in the state of Rio de Janeiro, in the southeast of Brazil. The type locality of this species is municipality of Aurá in the state of Pará. Vieira et al. (2008) when analysing samples of helminths of wild carnivore mammals from Brazil stored in CHIOC, observed specimens of $P$. gethi collected in E. barbara, G. cuja and the grisson Galictis vittata (Schreber,
Table 1

Comparison of morphometric features of females of Pachysentis gethi described by Machado-Filho (1950) and the current study.

\begin{tabular}{lll}
\hline & $\begin{array}{l}\text { Machado-Filho } \\
(1950)\end{array}$ & Current study \\
\hline Trunk length $(\mathrm{mm})$ & $15-25$ & $11-14$ \\
Proboscis length $(\mu \mathrm{m})$ & $583-794$ & $500-600$ \\
Number of hooks & 42 & 42 \\
Hook length type 1 $(\mu \mathrm{m})$ & 210 & $190-200$ \\
Hook length type 2 $(\mu \mathrm{m})$ & 210 & $180-210$ \\
Hook length type 3 $(\mu \mathrm{m})$ & 138 & $130-150$ \\
Hook length type 4 $(\mu \mathrm{m})$ & 96 & $90-100$ \\
Hook length type 5 $(\mu \mathrm{m})$ & 84 & $80-85$ \\
Hook length type 6 $(\mu \mathrm{m})$ & 71 & $60-70$ \\
Eggs length $(\mu \mathrm{m})$ & 84 & $80-90$ \\
Eggs width $(\mu \mathrm{m})$ & 54 & $50-60$ \\
Host species & Eyra barbara & Galictis cuja \\
Localities (states) & (type host) & Rio de Janeiro \\
& Pará (type & \\
\hline
\end{tabular}

1776) (Carnivora, Mustelidae). These last 2 hosts had not been reported as hosts of $P$. gethi by Machado-Filho (1950), and were considered new hosts for this acanthocephalan species. However, the record labels of 2 samples of paratypes of $P$. gethi stored in CHIOC (Nos. 9203 and 17838) that were originally associated with E. barbara in the study of Machado-Filho (1950), report that these were collected in specimens of $G$. cuja from the state of Rio de Janeiro. Therefore, these samples of G. cuja in the state of Rio de Janeiro were erroneously associated to E. barbara by Machado-Filho (1950). Since the study by Machado-Filho (1950) which described P. gethi with samples of acanthocephalans collected during the first half of 20th century, this species had never been recorded again. Therefore, this study constitutes the rediscovery of this species of Pachysenthis after 65 years of a unique and last record.

\section{Acknowledgements}

Pilar Corrêa was supported by a student fellowship from Coordenação de Aperfeiçoamento de Pessoal de Nível Superior, Brazil. Fabiano Matos Vieira was supported by a Postdoctoral fellowship from Programa Nacional de Pós-doutorado (PNPD) CAPES/FIOCRUZ (Fundação Instituto Oswaldo Cruz) at the Programa de Pós-graduação em Biodiversidade e Saúde (PPGBS) of the Instituto Oswaldo Cruz (IOC), Rio de Janeiro, RJ.

\section{References}

Amin, O. M. (2013). Classification of the Acanthocephala. Folia Parasitologica, 60, 273-305.

Bornholdt, R., Helgen, K., Koepfli, K. P., Oliveira, L., Lucherini, M., \& Eizirik, E. (2013). Taxonomic revision of the genus Galictis (Carnivora: Mustelidae): species delimitation, morphological diagnosis, and refined mapping of geographical distribution. Zoological Journal of the Linnean Society, 167, 449-472.

Machado-Filho, D. A. (1950). Revisão do gênero Prosthenorchis Travassos, 1915 (Acanthocephala). Memórias do Instituto Oswaldo Cruz, 48, 495-545. 
Meyer, A. (1931). Neue Acanthocephalen aus dem Berliner Museum. Bergründung eines neuen Acanthocephalensystems auf Grund einer Untersuchung der Berliner Sammlung. Zoologische Jahrbücher, Abteilung für Systematick, Ökologie und Geographie der Tiere, 62, 53-108.

Schmidt, G. D. (1972). Revision of the Class Archiacanthocephala Meyer, 1931 (Phylum Acanthocephala), with emphasis on Oligacanthorhynchidae Southwell et Macfie, 1925. Journal of Parasitology, 58, 290-297.
Vieira, F. M., Luque, J. L., \& Muniz-Pereira, L. C. (2008). Checklist of helminth parasites in wild carnivore mammals from Brazil. Zootaxa, 1721, $1-23$.

Yensen, E., \& Tarifa, T. (2003). Galictis cuja. Mammalian Species, 728, $1-8$. 